\title{
Results of Oral TRH Test in the Differentiation of Compensated and Decompensated Autonomous Thyroid Nodules
}

\author{
D. Jüngst ${ }^{1}$, U. Büll ${ }^{2}$, and H.J. Karl ${ }^{1}$ \\ Departments of Medicine $2^{1}$ (Director Prof. Dr. G. Paumgartner) and Radiology ${ }^{2}$ (Director Prof. Dr. J. Lissner), \\ Klinikum Grosshadern, University of Munich
}

Summary. In 17 patients with compensated autonomous adenomas of the thyroid, iv thyrotropin releasing hormone (TRH) tests $(200 \mu \mathrm{g})$ and oral TRH tests $(40 \mathrm{mg})$ were performed. In nine of these patients, thyroid-stimulating hormone (TSH) $30 \mathrm{~min}$ after iv TRH showed a normal $(>2.7 \mu \mathrm{U} / \mathrm{ml})$ and in eight patients a subnormal $(<2.7 \mu \mathrm{U} / \mathrm{ml})$ or negative response. However, after prolonged oral stimulation with $40 \mathrm{mg}$ TRH, after $120-180 \mathrm{~min}$ TSH was normal $(>2.7 \mu \mathrm{U} / \mathrm{ml})$ in 15 and subnormal $(<2.7 \mu \mathrm{U} / \mathrm{ml})$ in two patients.

In 20 patients with decompensated autonomous thyroid nodules, TSH was not detectable $(<0.8 \mu \mathrm{U} / \mathrm{ml})$ after iv or oral TRH stimulation. Therefore, the oral TRH stimulation test seemed to be superior to the iv TRH test in the discrimination of compensated and decompensated autonomous adenomas of the thyroid.

Key words: Autonomous thyroid nodules - Oral TRH test - Results

Ergebnisse des oralen TRH-Tests zur Unterscheidung von kompensierten und dekompensierten autonomen Adenomen der Schilddrüise

Zusammenfassung. Bei 17 Patienten mit kompensierten autonomen Adenomen der Schilddrüse wurden TRH-Teste mit $200 \mu \mathrm{g}$ i.v. und $40 \mathrm{mg}$ oral durchgeführt. Bei 9 Patienten war TSH $30 \mathrm{~min}$ nach TRH i.v. normal $(>2.7 \mu \mathrm{U} / \mathrm{ml})$, dagegen zeigten 8 Patienten einen subnormalen $(<2.7 \mu \mathrm{U} / \mathrm{ml})$ oder fehlenden TSH-Anstieg. Nach verlängerter Stimulation mit $40 \mathrm{mg}$ TRH oral war TSH 120-180 min bei 15 Patienten im Normbereich $(>2.7 \mu \mathrm{U} / \mathrm{ml})$ und nur bei 2 Patienten subnormal $(<2.7 \mu \mathrm{U} / \mathrm{ml})$.

Bei 20 Patienten mit dekompensierten autonomen Adenomen der Schilddrüse lag TSH sowohl nach i.v. als auch nach oraler TRH-Stimulation in allen Fällen unter der Nachweisgrenze $(<0.8 \mu \mathrm{U} / \mathrm{ml})$.

Die Befunde sprechen dafür, daß der orale TRH-Test geeigneter ist als der i.v. TRH-Test, um zwischen kompensierten und dekompensierten autonomen Adenomen der Schilddrüse zu unterscheiden.

Schliisselwörter: Autonomes Adenom - Oraler TRH-Test - Ergebnisse

\section{Introduction}

Patients with scintigraphically decompensated autonomous thyroid nodules usually reveal negative intravenous $200 \mu \mathrm{g}$ TRH tests [3].

Offprint requests to: Dr. D. Jüngst (address see page 478)
However. surprisingly comparable test results have been obtained in about $30 \%$ of patients with scintigraphically compensated autonomous adenomas [2]. Therefore, diagnosis of compensated and decompensated autonomous thyroid nodules is based primarily on scintigraphic findings and only to a small extent on the results of in vitro parameters of thyroid function. However, the oral TRH stimulation test was introduced recently and has been believed to be useful in the evaluation of patients with impaired TSH reserve but euthyroid function [1. 4, 5]. In these studies, about 10\%-12\% of apparently euthyroid patients revealed negative intravenous $200 \mu \mathrm{g}$ TRH tests. In $50 \%-60 \%$ of these patients, autonomous production of thyroid hormones could be excluded by the $40 \mathrm{mg}$ oral TRH test. It was the aim of this study to evaluate whether the oral TRH test is superior to the iv TRH test in the discrimination of compensated and decompensated autonomous adenomas classified by nuclear imaging.

\section{Materials and Methods}

The study included a total of 37 outpatients $(12$ males and 25 females) with an age ranging from 30 to 82 years. Diagnosis of autonomous thyroid nodules was based on the results of nuclear imaging with ${ }^{99 \mathrm{~m}} \mathrm{Tc}$-pertechnate (employing a $20 \%$ uptake of the paranodular tissue as the discriminating value), including scintigraphy, after suppression with $60 \mu \mathrm{g} \mathrm{T}_{3}$ for 10 days in cases suspected to have compensated autonomous adenomas. In all patients, intravenous TRH tests were performed after an overnight fasting period with a boluslike injection of $200 \mu \mathrm{g}$ TRH and TSH-RIA (Henning, Berlin), $30 \mathrm{~min}$ after TRH application. For oral TRH tests, a $40 \mathrm{mg}$ tablet of TRH (Thyroliberin, Merck, FRG) was used and single TSH determinations were done after $120-180 \mathrm{~min}$. There was an interval of 2-6 weeks between the iv and oral TRH tests. $T_{4}$ was measured by enzyme immunoassay (Syva Company, Palo Alto, USA) and $T_{3}$ by radio immunoassay (Amersham-Buchler, Braunschweig, FRG)

Results.

In 17 patients ( 5 males and 12 females), scintigraphy after suppression revealed a formerly compensated autonomous adenoma. Concentrations of thyroid hormones were measured prior to application of $\mathrm{T}_{3} \cdot \mathrm{T}_{4}(5.4-10.8 \mu \mathrm{g} / \mathrm{dl}, \tilde{x}=7.4 \mu \mathrm{g} / \mathrm{dl})$ and $\mathrm{T}_{3}(1.0-2.9 \mathrm{ng} / \mathrm{ml}$, $\tilde{x}=1.9 \mathrm{ng} / \mathrm{ml}$ ) concentrations in plasma were mainly in the normal range.

Thyroid-stimulating hormone, $30 \mathrm{~min}$ after $200 \mu \mathrm{g}$ iv TRH $(0.8-14.6 \mu \mathrm{U} / \mathrm{ml}, \tilde{x}=2.7 \mu \mathrm{U} / \mathrm{ml})$, showed in nine patients a normal 
$(>2.7 \mu \mathrm{U} / \mathrm{ml})$ and in eight patients a subnormal $(<2.7 \mu \mathrm{U} / \mathrm{ml})$ or negative response. However, TSH $120-180 \mathrm{~min}$ after $40 \mathrm{mg}$ oral TRH was normal $(>2.7 \mu \mathrm{U} / \mathrm{ml})$ in 15 patients and subnormal $(<2.7 \mu \mathrm{U} / \mathrm{m} 1)$ in only two patients.

In 20 patients ( 7 males and 13 females) scintigraphy demonstrated a primarily decompensated autonomous adenoma. In such cases, $30 \%-40 \%$ of $\mathrm{T}_{4}(4.0-14.6 \mu \mathrm{g} / \mathrm{dl}, \tilde{x}=7.8 \mu \mathrm{g} / \mathrm{dl})$ and $\mathrm{T}_{3}$ $(1.64 .3 \mathrm{ng} / \mathrm{ml}, \tilde{x}=2.3 \mathrm{ng} / \mathrm{ml})$ values were elevated. Thirty minutes after $200 \mu \mathrm{g}$ iv TRH and $120-180 \mathrm{~min}$ after $40 \mathrm{mg}$ oral TRH, TSH was not detectable $(<0.8 \mu \mathrm{U} / \mathrm{ml})$ in all cases in accordance with the scintigraphic findings of decompensated autonomous thyroid nodules.

\section{Discussion}

Patients with scintigraphically decompensated autonomous thyroid nodules usually reveal negative iv $200 \mu \mathrm{g} \mathrm{TRH}$ tests. These data could be confirmed in the present study.

Nearly $50 \%$ of the 17 patients with scintigraphically compensated autonomous thyroid nodules revealed a subnormal or negative response to IV TRH in accordance with prior studies [2]. However, prolonged stimulation with $40 \mathrm{mg}$ oral TRH in these patients was associated with normal TSH response in $15(88 \%)$ and subnor$\mathrm{mal}$ in two $(12 \%)$. All patients with decompensated autonomous thyroid nodules showed a failing TSH response to iv TRH and even to prolonged oral TRH stimulation.

These findings point to a possible clinical validity of the oral TRH test as a help in the differentiation of compensated and decompensated autonomous adenomas, especially in borderline cases. In addition, in patients scintigraphically suspected to have compensated thyroid nodules, a negative result of an oral TRH test may help to exclude this diagnosis and prevent further diagnostic procedures, e.g., the $T_{3}$-suppression-test.

Acknowledgements. $\mathrm{T}_{4}, \mathrm{~T}_{3}$ and TSH determinations were provided by Prof. Dr. W. Vogt, Bereich Endokrinologie und Stoffwechsel- chemie, Institute of Clinical Chemistry (Direktor Prof. Dr. M. Knedel), Klinikum Grosshadern University of Munich.

\section{References}

1. Jüngst D, Schineis E, Vogt W, Mann K, Karl HJ (1980) Parameters of thyroid function in thyroid autonomy. $J$ Mol Med 4:103-109

2. Ribka A, Mayr B, Büll U, Leisner B, Scriba PC (1979) Wertigkeit nuklearmedizinischer und endokrinologischer Methoden zur Klassifizierung autonomer Schilddrüsenadenome. Med Klin $74: 511-515$

3. Ridgway EC, Weintraub BD, Cellalos JL, Rack MC, Maloof F (1973) Suppression of pituitary TSH secretion in the patient with a hyperfunctioning thyroid nodule. J Clin Invest $52: 2783-2790$

4. Staub JJ, Girard J, Gemsenjäger E (1976) Entwicklung eines einfachen oralen Kurztestes mit dem TSH-Releasing-Hormon (TRH) und dessen Anwendung in der Schilddrüsendiagnostik. Schweiz Med Wochenschr 106:1839-1842

5. Vogt P, Girard J, Staub JJ (1978) Thyroid-Stimulating Hormone (TSH), Triiodothyronine $\left(\mathrm{T}_{3}\right)$ and Thyroxine $\left(\mathrm{T}_{4}\right)$ response to intravenous and oral stimulation with synthetic ThyrotropinReleasing-Hormone (TRH) in young healthy adults. Klin Wochenschr $56: 31-35$

Received October 23, 1981

Accepted November 8, 1981

Dr. D. Jüngst

Med. Klinik 2

Klinikum Großhadern

Marchioninistr. 15

D-8000 München 70

Federal Republic of Germany

Verantwortlich für den Textteil: Prof. Dr. Herbert Schwiegk und Prof. Dr. Hans Jahrmärker. Medizinische Klinik (Innenstadt) der Universität, Ziemssenstraße 1. D-8000 München 2; für den Anzeigenteil: E. Lückermann. R. Eicke, Springer-Verlag. Kurfürstendamm 237. D-1000 Berlin 15. - Springer-Verlag. 